\title{
Fiscal Consolidation During a Depression
} Nitika Bagaria, Dawn Holland and John Van Reenen

\author{
Special Paper No. 27
}

August 2012

\section{Centre for Economic Performance Special Paper}

Nitika Bagaria is an Occasional Research Assistant with the Productivity and Innovation Programme at the Centre for Economic Performance, London School of Economics and Political Science. Dawn Holland is a Senior Research Fellow at the National Institute of Economic and Social Research, London. John Van Reenen is the Director of CEP and Professor of Economics, London School of Economics and Political Science. 


\begin{abstract}
In 2009-10, the UK's budget deficit was about 11 per cent of GDP. A credible plan for fiscal consolidation was introduced in the UK over the fiscal years 2011-12 to 2016-17. In this paper, we assess the impact of the scale and timing of this fiscal consolidation programme on output and unemployment in the UK. During a prolonged period of depression when unemployment is well above most estimates of the NAIRU, the impact of fiscal tightening may be different from that in normal times. We contrast three scenarios: the consolidation plan implemented during a depression; the same plan, but with implementation delayed for three years when the economy has recovered; and no consolidation at all. The modelling confirms that doing nothing was not an option and would have led to unsustainable debt ratios. Under both our "immediate consolidation" scenario and the "delayed consolidation", the necessary increases in taxes and reductions in spending reduce growth and increase unemployment, as expected. But our estimates indicate that the impact would have been substantially less, and less long-lasting, if consolidation had been delayed until more normal times. The impact is partly driven by the heightened magnitude of fiscal multipliers, and exacerbated by the prolongation of their impact due to hysteresis effects. The cumulative loss of output over the period 2011-21 amounts to about $£ 239$ billion in 2010 prices, or about 16 per cent of 2010 GDP. And unemployment is considerably higher for longer - still 1 percentage point higher even in 2019.
\end{abstract}

\title{
Acknowledgements
}

The authors are grateful to Simon Kirby, who provided the details of the UK budget plans in table 1 that underlie all the scenarios in this note, as well as the UK forecast baseline reported in figures 9-11. We would also like to thank Angus Armstrong, Richard Layard, Katerina Lisenkova and Jonathan Portes for useful discussion and comments on the modelling work and paper. All errors remain our own. 


\section{Fiscal Consolidation During A Depression}

\section{Nitika Bagaria, Dawn Holland and John Van Reenen}

The financial crisis and resulting recession led to sharp rises in government deficits in almost all major industrialized countries, primarily because of falls in tax receipts. This was further increased by fiscal stimulus packages and emergency financial sector support. This in turn has led to a sharp rise in global government debt, giving rise to concerns about long-term fiscal sustainability. Despite this, long-term interest rates remain low in virtually all major developed economies outside the Euro Area, reflecting the fact that growth is weak and short-term interest rates are expected to remain low. However, many of the major economies have introduced fiscal tightening measures in recent years despite the widespread slowdown in GDP growth, and a level of GDP that remains well below that of 2007. The IMF estimates that the overall global fiscal position tightened by 1 per cent of GDP in 2011 (IMF, 2012a). Meanwhile, in the Euro Area, where countries can neither finance their deficits through quantitative easing nor adjust via the exchange rate, market pressures on some countries have been intense, and austerity programmes have been introduced in a number of countries in an attempt to stem the rise in sovereign debt and ease the pressure on bond yields.

Although the long-term government borrowing rates are at historic lows in the UK, it is clearly the case that over the medium to long term fiscal consolidation is essential for debt sustainability. The UK has announced fiscal consolidation measures amounting to a total of 7.4 per cent of GDP over the fiscal years 2011-12 to 2016-17. Table 1 details the current plans by period and instrument.

In this paper we assess the impact of the scale and timing of this fiscal consolidation programme on output and unemployment in the UK. We begin by using the National Institute's model, NiGEM, to analyze the impact of the ongoing policy on the UK economy using the standard version of the model, which would reflect the impact in 'normal' times. However, we do not appear to be in 'normal' times but in a prolonged period of depression, which we define as a period when output is depressed below its previous peak. As Delong and Summers (2012), Auerbach and Gorodnichenko (2012) and others point out, the impact of fiscal tightening during a depression may be different from that in normal times.

There are a number of channels that the differences may feed through; for each we modify NiGEM to take account of the differential impacts. First, there is the interest rate response. Under normal circumstances a tightening in fiscal policy can be expected to be accommodated by a relaxation in monetary policy. However, with interest rates already at exceptionally low levels, further tightening of fiscal policy is unlikely to result in such an offsetting monetary policy reaction. While quantitative easing/credit easing measures have been introduced, the effects of these measures are also limited by low interest rates on 'riskfree' assets. It is less clear that monetary easing measures have a significant impact on the risk premia attached to assets that bear a greater risk of default. 
Table 1. Fiscal consolidation plans

\begin{tabular}{|c|c|c|c|c|c|c|c|}
\hline & $\begin{array}{r}2011- \\
12\end{array}$ & $\begin{array}{r}2012- \\
13\end{array}$ & $\begin{array}{r}2013- \\
14\end{array}$ & $\begin{array}{r}2014- \\
15\end{array}$ & $\begin{array}{r}2015- \\
16\end{array}$ & $\begin{array}{r}2016- \\
17\end{array}$ & $\begin{array}{r}\text { Cumula } \\
\text { tive }\end{array}$ \\
\hline \multicolumn{8}{|l|}{ Spending } \\
\hline Consumption & -0.44 & -0.76 & -0.46 & -0.78 & -0.81 & -0.34 & -3.58 \\
\hline Investment & -0.27 & -0.28 & -0.36 & -0.04 & -0.22 & 0.00 & -1.16 \\
\hline Transfers to & & & & & & & \\
\hline households & -0.09 & -0.20 & -0.37 & -0.19 & -0.03 & 0.02 & -0.85 \\
\hline Subsidies & -0.05 & 0.01 & -0.02 & 0.00 & -0.01 & 0.00 & -0.07 \\
\hline Revenue & & & & & & & \\
\hline $\begin{array}{l}\text { Direct tax, } \\
\text { households }\end{array}$ & 0.10 & 0.40 & 0.20 & 0.33 & -0.11 & 0.01 & 0.92 \\
\hline $\begin{array}{l}\text { Direct tax, } \\
\text { business }\end{array}$ & 0.15 & 0.01 & 0.04 & -0.12 & -0.02 & 0.02 & 0.08 \\
\hline Indirect tax & 0.70 & 0.00 & 0.09 & 0.03 & -0.06 & -0.02 & 0.76 \\
\hline Total & 1.80 & 1.64 & 1.54 & 1.24 & 0.87 & 0.33 & 7.42 \\
\hline
\end{tabular}

Note: Here we define the fiscal impulse as the ex-ante expected change in revenue/spending (as a \% of GDP) as a result of announced policy changes. Tax credit policy changes are classified as changes to direct taxes in this analysis. The impact on GDP will depend on the fiscal multipliers in each country, and cannot be read directly from this table. The ex-post impact on government balances will depend on the response of GDP and the endogenous response of government interest payments, and so also cannot be read directly from this table.

Second, during a downturn, when unemployment is high and job security low, a greater percentage of households and firms are likely to find themselves liquidity constrained. This is likely to be particularly acute when the downturn is driven by an impaired banking system, as lending conditions will tighten beyond what would be expected in a normal downturn. There is less scope to smooth consumption in response to short-term income losses through an adjustment in savings.

Finally, long spells of depressed output and high unemployment can lead to 'hysteresis' which keeps the productive capacity of the economy persistently or even permanently lower (for example through the 'scarring' effect of unemployment which we discuss below). The economy may converge to the steady state levels of output and employment in the very long run, but in the medium term output levels could be substantially lower due to hysteresis effects. The time the economy takes to converge to the long-run steady state is also prolonged.

In this note we consider the potential impact on the economy, both in the short and long term, of postponing the planned consolidation measures that were introduced from 2011-12 onwards until the UK economy has emerged from the current period of depression and the output gap has narrowed significantly. While our analysis is not strictly dependent on the length of this delay, NiGEM-based estimates suggest that, in the absence of fiscal tightening, the output gap in the UK would be approaching balance by 2014. In the absence of deeper and more prolonged financial distress driven by events in the Euro Area, we would then have anticipated a 'normal' response to the fiscal consolidation measures after 2014, rather than the rather larger response that may result in the current period of depressed output and high unemployment.

In order to decompose the channels of transmission, we present four separate scenarios. In the first scenario, we illustrate the expected impact on output and employment of the fiscal 
programme detailed in table 1 , had it been introduced in normal times, rather than during a period of depression. We then consider, one at a time, three channels that may differ during a period of depression: the impacts of an impaired interest rate channel; the impacts of heightened liquidity constraints; and the impacts of hysteresis, all of which exacerbate the impact of the consolidation programme on output and unemployment. In the final section, we construct a combined scenario that cumulates the effects of all three channels, and illustrates our estimate of the impact of the consolidation programme as it has been put forward, during a period of depression with limited downward flexibility in interest rates, heightened liquidity constraints and rising levels of long-term unemployment. We compare this to a scenario with no fiscal consolidation, and one where the same consolidation programme is introduced with a delay (2014-20), when the economy is expected to have returned to normal conditions. This allows us to estimate the cumulative impact that may be associated with the early introduction of the consolidation programme.

\section{Scenario 1: Impact of fiscal programme in normal times}

Fiscal multipliers ${ }^{1}$ are not uniform either across countries (e.g. Ilzetzki et al., 2010), across time or across instruments (e.g. tax vs. spending). Barrell et al. (2012) provides an overview of NiGEM and compares estimates of fiscal multipliers across instruments for a set of seventeen OECD economies. In general, spending multipliers tend to be larger than tax multipliers in the first year, as tax adjustments are partially offset through savings and feed in more gradually. For the UK, they find a direct spending multiplier of about $0.5-0.7$ per cent in the first year, while tax multipliers averaged about $0.1-0.2$ per cent. $^{2}$ Much of the current consolidation plan is spending based, and so can be expected to have a more significant impact on GDP in the short term.

In figure 1, we illustrate the impact on the level of GDP and the unemployment rate that we would expect in response to the current fiscal programme outlined in table 1, were it introduced in 'normal' times, e.g. when the output gap is close to balance and unemployment is close to its equilibrium level. We hold the exchange rate fixed in this scenario, as exchange rate behaviour depends not just on the policy adopted in the UK, but on the relative stance of UK fiscal policy in a global context. Where many major economies are consolidating simultaneously, the assumption of a neutral impact on the exchange rate is probably justified. If the UK is tightening relatively more than its trading partners, we would expect to see a modest depreciation of the exchange rate, whereas if it is tightening relatively less than its partners the exchange rate would appreciate, holding all other risk factors constant.

We would expect the level of output to decline by 0.4 per cent relative to the baseline in the first year, reaching a peak of 2.3 per cent below base after six years. Over the longer term, we would expect both GDP and unemployment to return to levels that would have been anticipated in the absence of fiscal consolidation. The normal cyclical behaviour of the model suggests that output would rise slightly above base and unemployment fall slightly below base after year 11, although these effects would not persist over the longer term. The loss of government investment can be expected to have a negative impact on the productive capacity of the economy in the longer term, but these effects are relatively small. Unemployment is brought back towards base levels as output recovers, and through an adjustment in real wages. 
Figure 1. Impact of fiscal consolidation in normal times

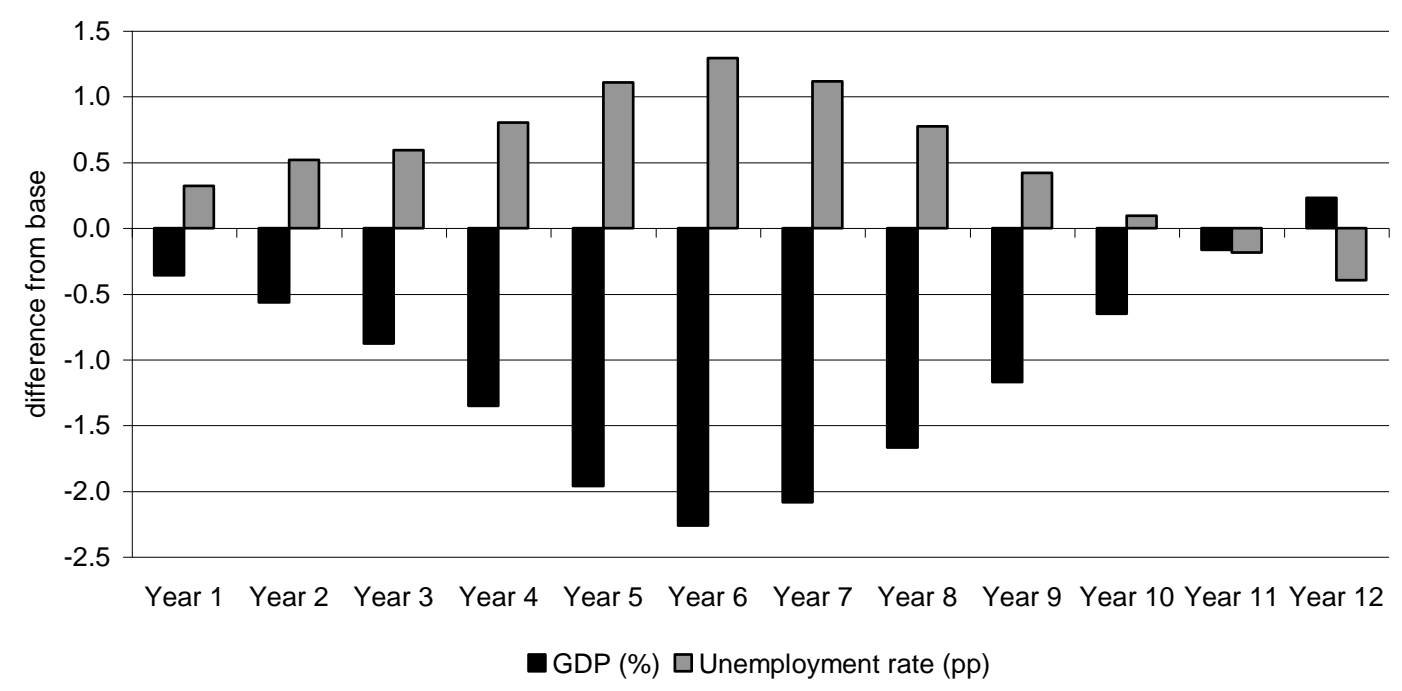

Notes: Impact of policies described in table 1 on the level of GDP and the unemployment rate, if introduced when the output gap is close to 0 and the unemployment rate is close to its long-run equilibrium.

Source: NiGEM simulations

In general, a fiscal tightening can be expected to be accompanied by a monetary loosening, as an inflation targeting central bank maintains a given inflation target with lower rates of interest. However, not all fiscal instruments have the same impact on inflation. One of the instruments employed in the fiscal consolidation programme outlined in table 1 is the indirect tax, or VAT, rate. A rise in the VAT rate will initially put upward pressure on inflation, as it is a direct shock to the price level. This may induce an inflation targeting central bank to raise interest rates in the short term. After the first year or so, the jump in the price level would fall out of the inflation rate, and we would expect inflation to be somewhat below what it would have been in the absence of the VAT rise, allowing a lower interest rate over the medium term.

Our preliminary scenario reflecting the response in 'normal' times allows an endogenous response in short-term interest rates. ${ }^{3}$ In normal times, the fiscal programme described in table 1 would initially put upward pressure on interest rates, as the indirect tax rate rises by 250 basis points, with a direct impact on inflation in the first year of the shock. As the effects of the VAT rise dissipate, this is followed by an extended period of short-term policy interest rates below base. With forward-looking financial markets, the long-term interest rate, which determines the borrowing costs of firms for investment, is driven by the expected path of short-term interest rates over a 10-year forward horizon. As such, despite the initial rise in the short-term rates, long-term interest rates fall immediately, stimulating investment and offsetting part of the fiscal contraction. The expected impact on short-term and long-term interest rates in response to the policy, were it to be introduced during 'normal' times, is illustrated in figure 2. Long-term interest rates would be expected to fall by about 150 basis points for an extended period, allowing a strong boost to investment. 
Figure 2. Impact of fiscal consolidation on interest rates in normal times

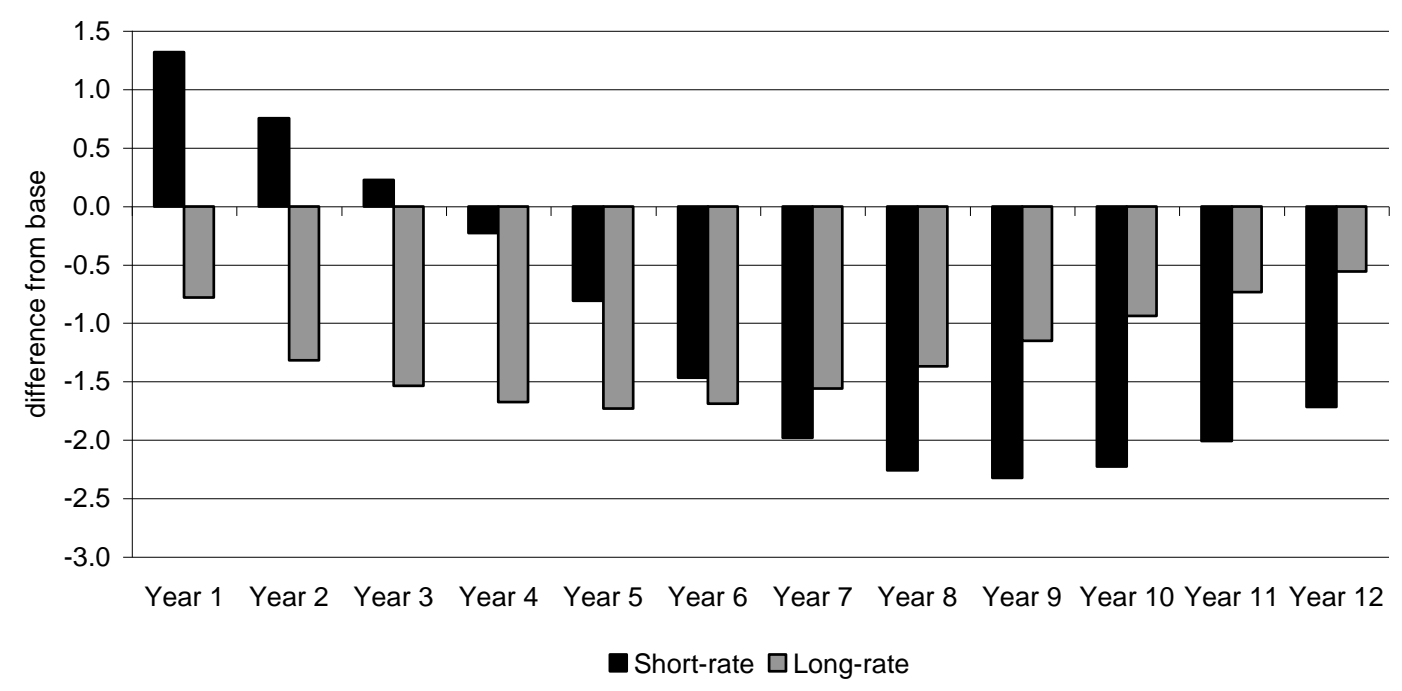

Notes: Impact of policies described in table 1 on interest rates, if introduced in 'normal' times. Short-term interest rates are determined by a central bank policy rule that targets inflation; long-term interest rates allow for 'rational' or out-turn consistent expectations in financial markets.

Source: NiGEM simulations

\section{Impact of a fiscal programme in a depressed economy}

\section{Scenario 2: Impaired interest rate channel}

In the previous section we considered the impact of a fiscal consolidation in normal times, and demonstrated that, under normal circumstances, the consolidation programme detailed in table 1 would be expected to reduce long-term interest rates by about 150 basis points for several years. However, when interest rates are close to zero, their downward flexibility may be restricted (the 'zero lower bound'). With no offsetting stimulus from lower interest rates, the impact of the fiscal consolidation programme on GDP would be somewhat higher. Tenyear government bond yields in the UK are not at zero, but are exceptionally low, suggesting that there may be little scope for further reductions. If we hold long-term interest rates fixed, rather than allowing them to decline as in the first scenario, the negative effects on output and unemployment would be amplified. Figures 3 and 4 compare the impact on GDP and the unemployment rate under normal times with an endogenous interest rate response, to the same consolidation programme in an environment where there is no downward flexibility of interest rates. The impact on GDP would be about $1 \frac{1 / 2}{2}$ per cent greater after four years if the interest rate adjustment channel is impaired, while the unemployment rate would be expected to rise by a further $3 / 4$ percentage point. 
Figure 3. Impact of an impaired interest rate adjustment on GDP

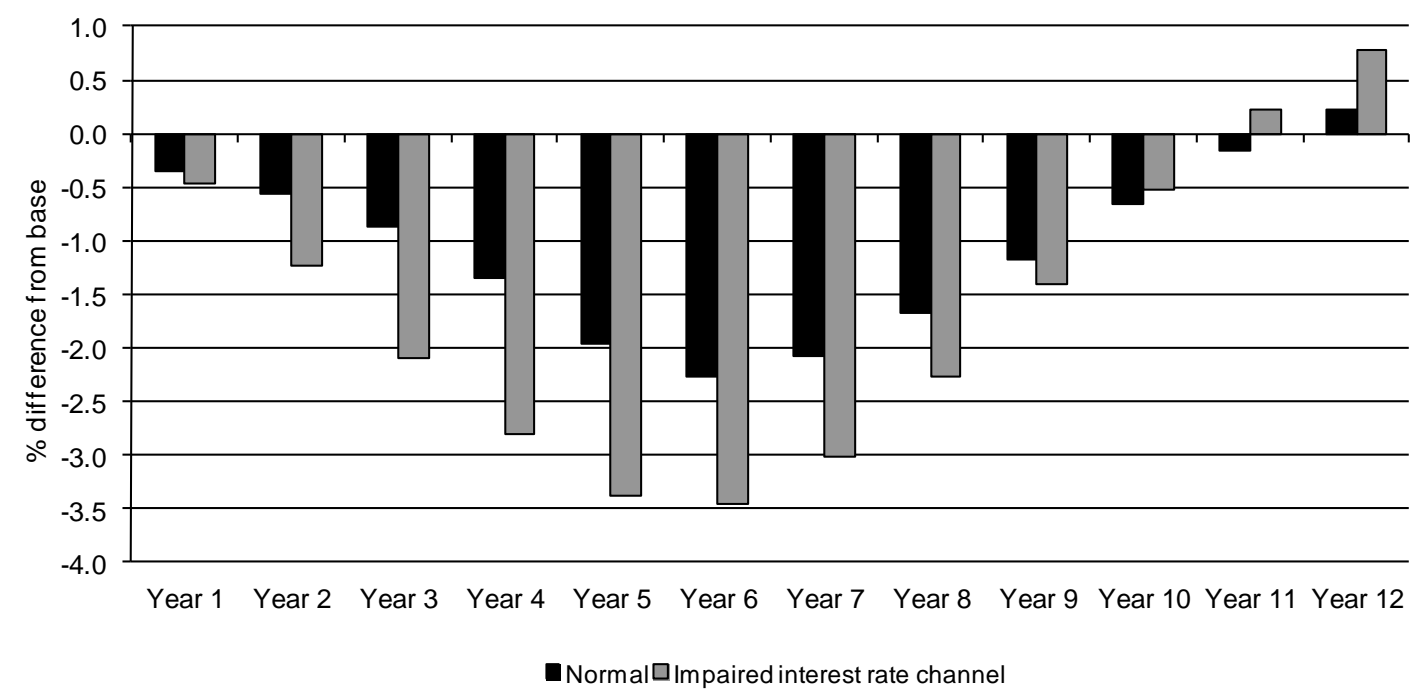

Notes: Impact on the level of GDP from figure 1 and under the same scenario with the interest rate adjustment impaired.

Source: NiGEM simulations

\section{Figure 4. Impact of an impaired interest rate adjustment on unemployment rate}

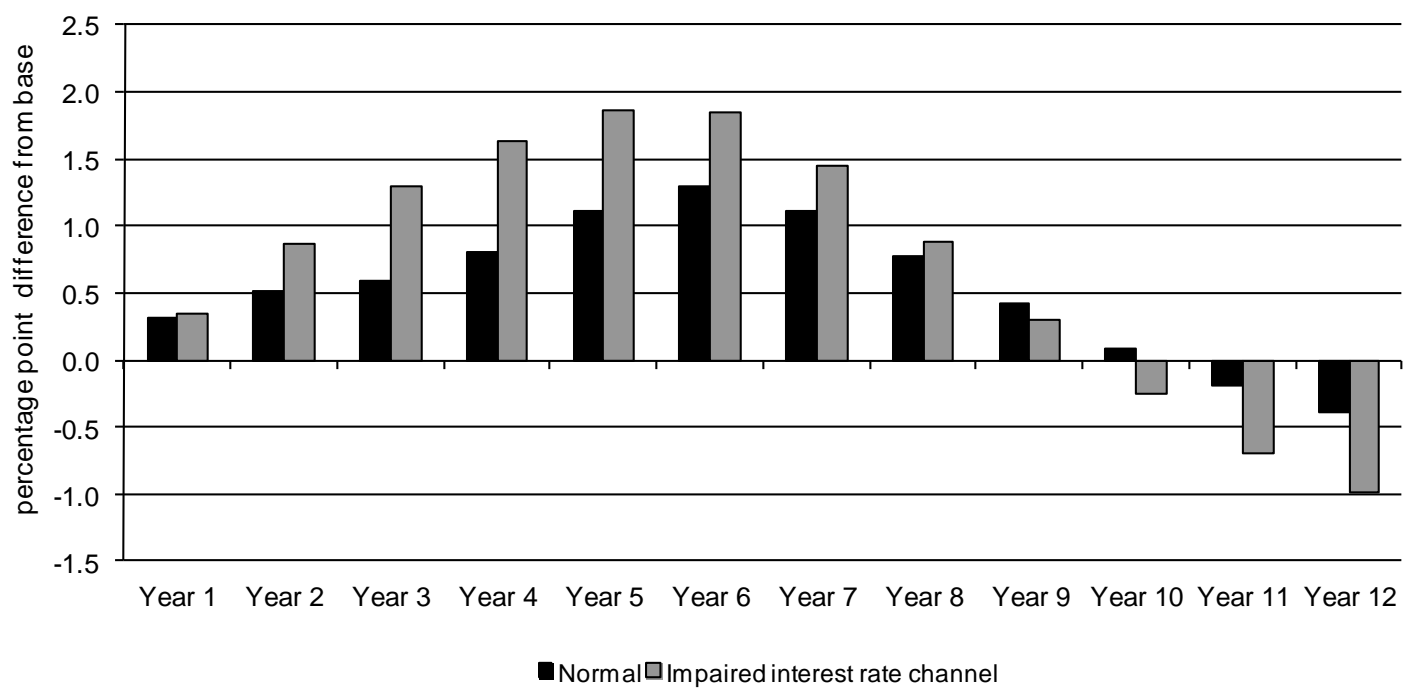

Notes: Impact on the unemployment rate from figure 1 and under the same scenario with the interest rate adjustment impaired.

Source: NiGEM simulations

\section{Scenario 3: Heightened liquidity constraints}

In the presence of perfect capital markets and forward-looking consumers with perfect foresight, households will smooth their consumption path over time, and consumer spending will be largely invariant to the state of the economy or temporary fiscal innovations. In the extreme example of a fully Ricardian world, the fiscal multiplier is effectively zero, as fiscal policy will simply be offset by private sector adjustments to savings behaviour. However, at any given time, some fraction of the population and of firms is liquidity constrained; that is, they have little or no access to borrowing, so that their current spending is largely restrained by their current income. In the first scenario, we make the assumption that savings behaviour and the number of liquidity constrained consumers and businesses are as in normal times. 
However, in a prolonged period of depressed activity, this is unlikely to be the case, especially when the downturn has at its roots an impaired banking system. In this section we consider the effects of an increase in the share of consumers and firms that are liquidity constrained. We operationalize this effect in the NiGEM model through an adjustment to the short-term income elasticity of consumption and investment. If liquidity constraints are not important, households and firms can borrow when incomes or profits are low in order to smooth their spending path. In this case, the path of consumption and investment will be less sensitive to short-term fluctuations in income or profits. However, when liquidity constraints are high, there is less scope to borrow to smooth spending, and consumption and investment will be much more reliant on current revenue streams. A detailed illustration of the sensitivity of the scenarios to assumptions on the short-term income elasticity parameters is given in the Appendix.

In the standard version of NiGEM, the short-term income elasticity of consumption in the UK is given by 0.17 , suggesting a relatively low level of liquidity constraints. Barrell, Holland and Hurst (2012) put this into an internationally comparative context, which suggests that UK liquidity constraints are on the low side, but not out of line with other advanced economies. The short-term elasticity of investment to GDP is between 1 and 2 per cent, with business investment more sensitive to the state of the economy than housing investment.

We now consider the impact on output and unemployment that we would expect when liquidity constraints are heightened. Figures 4 and 5 illustrate the expected impact on output and the unemployment rate of the consolidation programme detailed in table 1 if it were introduced in 'normal' times (scenario 1), and compares this to a scenario with moderately heightened liquidity constraints (model 4 in the Appendix) and high liquidity constraints (model 7 in Appendix table A1). The moderate scenario can be interpreted as representing an environment where the number of liquidity constrained consumers is roughly double that in normal times, while the high liquidity constraints scenario reflects an environment where the number of liquidity constrained consumers is twice that in the moderate scenario. In all three scenarios we allow an endogenous adjustment of both short-term and long-term interest rates. Under high liquidity constraints, we would expect output to decline by $1 / 2$ per cent more in the first year than it would in normal times. The unemployment rate can be expected to increase by 0.25 percentage points more in the first year compared to the first normal times scenario. By year 7, the differences between the three scenarios are largely eliminated. 
Figure 5. Impact of liquidity constraints on GDP

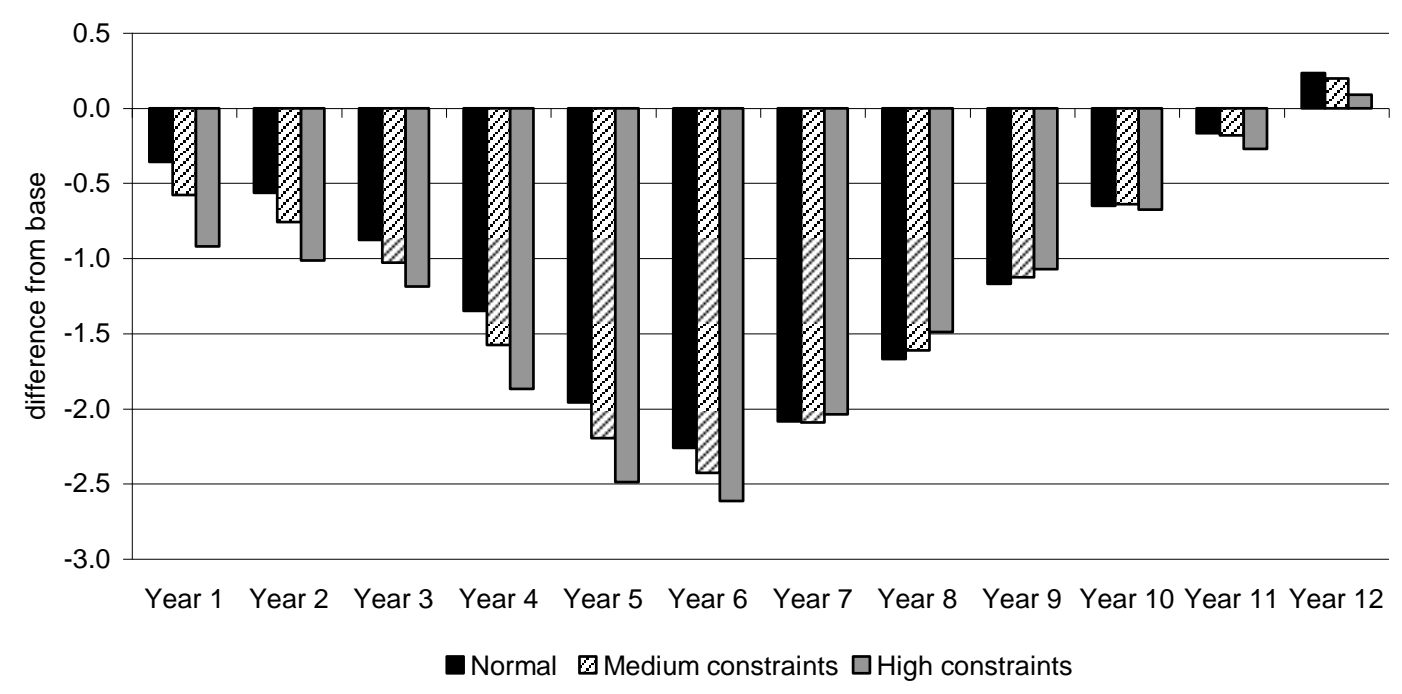

Notes: Impact of policies described in table 1 on GDP, if introduced in 'normal' times, and with heightened liquidity constraints. See models 4 and 7 in the Annex for details on the parameter assumptions.

Source: NiGEM simulations

\section{Figure 6. Impact of liquidity constraints on unemployment rate}

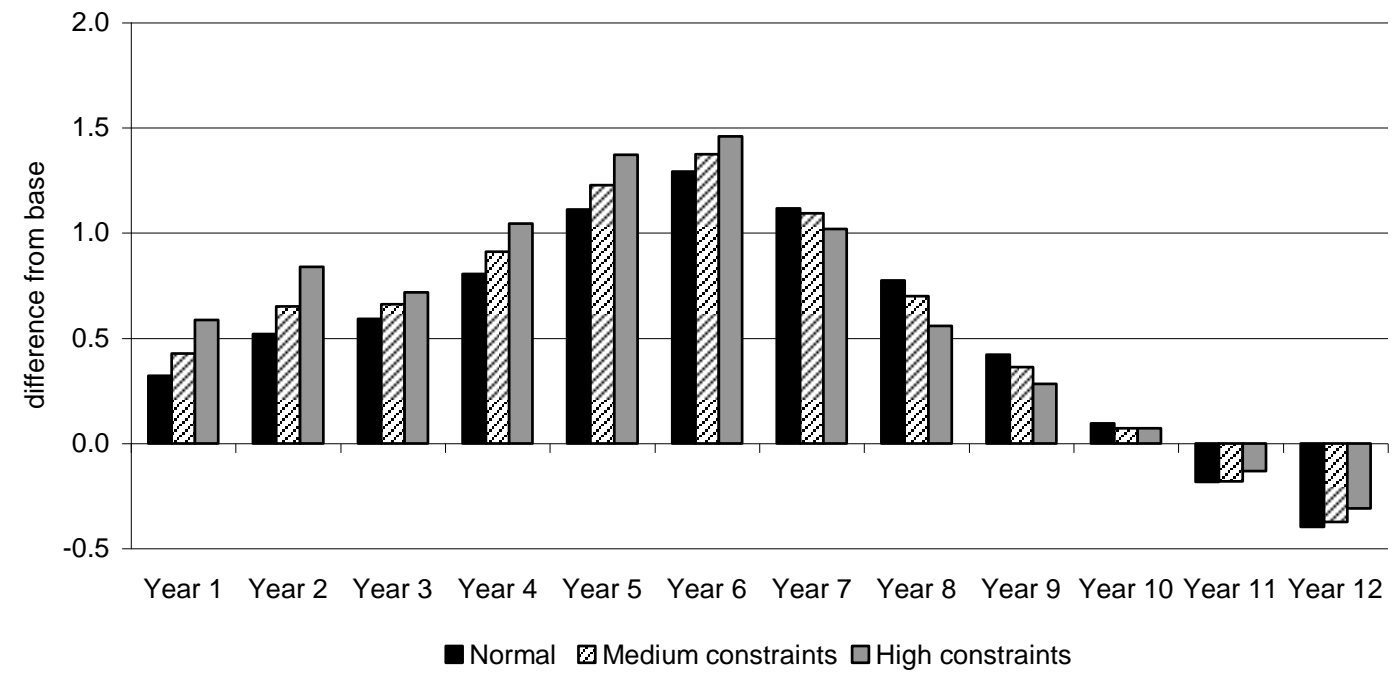

Notes: Impact of policies described in table 1 on unemployment rate, if introduced in 'normal' times, and with heightened liquidity constraints. See models 4 and 7 in the Annex for details on the parameter assumptions.

Source: NiGEM simulations

\section{Scenario 4: Presence of hysteresis}

Extended periods of depressed output and high unemployment can have long-term implications for the productive capacity of the economy. A host of mechanisms could be responsible for these hysteresis effects. These include reduced capital investment, premature capital scrapping, reduced labour force attachment on the part of the long-term unemployed resulting in lower wage pressures, scarring effects on young workers who have trouble beginning their careers and changes in managerial attitudes. In particular, the incidence of long-term unemployment may reduce the downward pressure on wages exerted by a high general unemployment rate and thus lead to unemployment hysteresis or persistence long 
after the shocks have dissipated. We focus on this labour market channel of hysteresis in this paper. This does not mean that the other potential channels of hysteresis are unimportant. ${ }^{4}$

A potential explanation of hysteresis effects is that a decrease in aggregate demand initially causes a rise in short-term unemployment, but this turns into long-term unemployment if the depression continues. As the survival rate (in unemployment) for the long-term unemployed is higher, ${ }^{5}$ they put less downward pressure on wages and inflation and so can contribute to the persistence of unemployment into the medium term. Machin and Manning (1999) model this in an efficiency wage framework. Similar results are found in Blanchard and Diamond (1994) in a matching model context, Calmfors and Lang (1995) and Manning (1993) in the context of a union bargaining model. Thus, high long-term unemployment has been argued to be a cause of high unemployment itself. However, it is still possible that the unemployment rate returns to its steady state NAIRU in the very long run.

Alternatively, it is highly likely that the long-term unemployed may cease to participate in the labour market altogether. There is sparse evidence on the decline in participation rate of those who have been unemployed for a prolonged period. More recently, it has been observed that in the US, the labour force participation rate plummeted during the Great Recession. It declined from a peak of 66.5 per cent in 2007 to 62 per cent in $2012 .^{6}$ The demographic trend relating to the retirement of the 'baby boom' generation, which has been ongoing since the turn of the century, is a slow-moving generational trend and cannot explain this substantial recent decline. This seems to suggest that this decline is at least in part a result of the labour market pressures arising from the 2008 crisis. $^{7}$ By contrast, in the UK, labour force participation has held up relatively well compared with previous recessions, although long-term unemployment has risen sharply.

The standard model for wages within NiGEM is based around a profit maximizing condition that sets the marginal product of labour equal to the real wage. The price and wage equations are determined by the first order profit maximizing conditions. Using a CES-style of production function, this can be described as:

$$
\ln \left(\frac{w}{p}\right)=\alpha+\frac{1}{\sigma} \ln \left(\frac{y c a p}{l}\right)-\frac{1-\sigma}{\sigma} t e c h l
$$

Where $w / p$ is the real wage, ycap is potential or capacity output, $l$ is labour input, techl is labour augmenting technical progress, $\sigma$ is the elasticity of substitution between labour and capital and $\alpha$ is a constant term.

This forms the long-run relationship and the firm side of the wage bargain. The unemployment rate acts as the bargaining instrument to bring labour demand in line with labour supply. We embed this into a dynamic equation of the form:

$$
\begin{aligned}
& \Delta \ln (w)=\omega_{1}+\omega_{2}\left\{\ln \left(\frac{w}{p}\right)_{-1}-\frac{1}{\sigma} \ln \left(\frac{y c a p}{l}\right)_{-1}+\frac{1-\sigma}{\sigma} \text { techl }_{-1}\right\} \\
& +\omega_{3} \Delta \ln (p)+\left(1-\omega_{3}\right) \Delta \ln \left(p^{e}\right)+\omega_{4}\left(U_{-1}\right)
\end{aligned}
$$

where $U$ is the unemployment rate, $\Delta$ is the difference operator, $\omega_{1}-\omega_{4}$ are parameters and superscript $e$ denotes expectations. 
When the unemployment rate rises, this puts downward pressure on real wage growth. Firms can then afford to employ more workers, which brings labour demand in line with labour supply, and pushes unemployment back towards its equilibrium.

Arguably, those who have been unemployed for an extended period of time begin to search for work less intensively, or because of 'scarring' effects on skills or motivation, may simply not be regarded as suitable potential workers by employers. They may thus exert less pressure on wages than those who have been unemployed for only a short period. A more sophisticated model would, therefore, differentiate the unemployed by their duration out of work, and allow the wage elasticity to decline as the duration rises. In order to allow for this form of hysteresis we consider what we define as the long-term unemployed (LTU) - those who have been unemployed for twelve months or longer - separately from total unemployment.

It is difficult to identify empirically differences in the wage elasticities of different groups of unemployed, given the very strong correlation among the duration groups and unobserved heterogeneity between groups. In order to calibrate the differences in wage pressure, we draw on the study by Elsby and Smith (2010), who calculate the unemployment-to-employment transition rate by duration for the UK (see figure 9, p. R35 in Elsby and Smith, 2010). Those unemployed for longer face markedly lower job-finding rates. Job seekers with more than twelve months duration find jobs at an average rate of just over 4 per cent per month, whereas the total pool of unemployed find jobs at an average rate of 10 per cent per month, using a sample that covers 1992-2010. This would suggest that long-term unemployed exert about 60 per cent less pressure on wages than the total pool of unemployed.

We, thus, construct an augmented wage equation, which incorporates wage-bargaining that is less sensitive to the long-term unemployment rate, using an equation of the form:

$$
\begin{aligned}
& \Delta \ln (w)=\omega_{1}+\omega_{2}\left\{\ln \left(\frac{w}{p}\right)_{-1}-\frac{1}{\sigma} \ln \left(\frac{y c a p}{l}\right)_{-1}+\frac{1-\sigma}{\sigma} \text { techl }_{-1}\right\} \\
& +\omega_{3} \Delta \ln (p)+\left(1-\omega_{3}\right) \Delta \ln \left(p^{e}\right)+\omega_{4}\left(U_{-1}\right)-0.6 \omega_{4}(L T U)_{-1}
\end{aligned}
$$

where $L T U$ is the long-term unemployment rate. We assume $\omega_{4}<0$ to reflect the bargaining process.

Some older studies, for example Nickell (1987), find a somewhat stronger feedback from LTU to wages. The sample used for estimation in his paper covers 1953-83, and so may be less relevant for today, given the significant changes to the labour market that have occurred since 1979. Nonetheless, we consider an alternative scenario, where the long-term unemployed have essentially stopped searching altogether, and so put no pressure on wages:

$$
\begin{aligned}
& \Delta \ln (w)=\omega_{1}+\omega_{2}\left\{\ln \left(\frac{w}{p}\right)_{-1}-\frac{1}{\sigma} \ln \left(\frac{y c a p}{l}\right)_{-1}+\frac{1-\sigma}{\sigma} \text { techl }_{-1}\right\} \\
& +\omega_{3} \Delta \ln (p)+\left(1-\omega_{3}\right) \Delta \ln \left(p^{e}\right)+\omega_{4}\left(U_{-1}-L T U_{-1}\right)
\end{aligned}
$$

This can be viewed as an upper limit to the potential effects through this channel. However, it should not be interpreted as an upper limit to the effects of hysteresis overall. Hysteresis may 
set in earlier than we allow for here - for example after six months rather than after twelve months. And the potential for labour market withdrawal could lead to significantly more prolonged effects on the productive capacity of the economy.

The impact of LTU on wages will also depend on how we model the rate of long-term unemployment itself. OECD (2009) estimates a simple relationship between the total unemployment rate and the long-term unemployment rate. For the UK, the relationship they identify is:

$$
L T U=0.76 * L T U_{-1}-0.29 * L T U_{-2}+0.34 * U
$$

We use this relationship, rewritten in error correction format, to model $L T U$ in the revised NiGEM model. The equation can be written as:

$$
\Delta L T U=0.29 * \Delta L T U_{-1}+0.34 * \Delta U-0.53\left\{L T U_{-1}-0.6 * U_{-1}\right\}
$$

Figures 7 and 8 illustrate the expected impact on output and the unemployment rate in the presence of labour market hysteresis effects, and compares our 'normal times' scenario to the two augmented wage equations discussed above - where the long-term unemployed exert 60 per cent less pressure on wages than shorter-term unemployed, and where the long-term unemployed exert no pressure on wages. In order to decompose the effects, we assume the interest rate channel is not impaired and liquidity constraints are not important. An important point of comparison with the baseline (scenario 1) is the much slower speed with which output returns to supply equilibrium; in other words, hysteresis not only magnifies the negative impacts of fiscal consolidation on output and employment, but means that they are much more long-lasting.

By introducing tightening during a period of high unemployment and large output gap, the negative impacts of the consolidation programme can be expected to persist for 2-4 years longer than they would have if the policy had been postponed until the level of unemployment had reverted to its long-run equilibrium. 
Figure 7. Impact on GDP

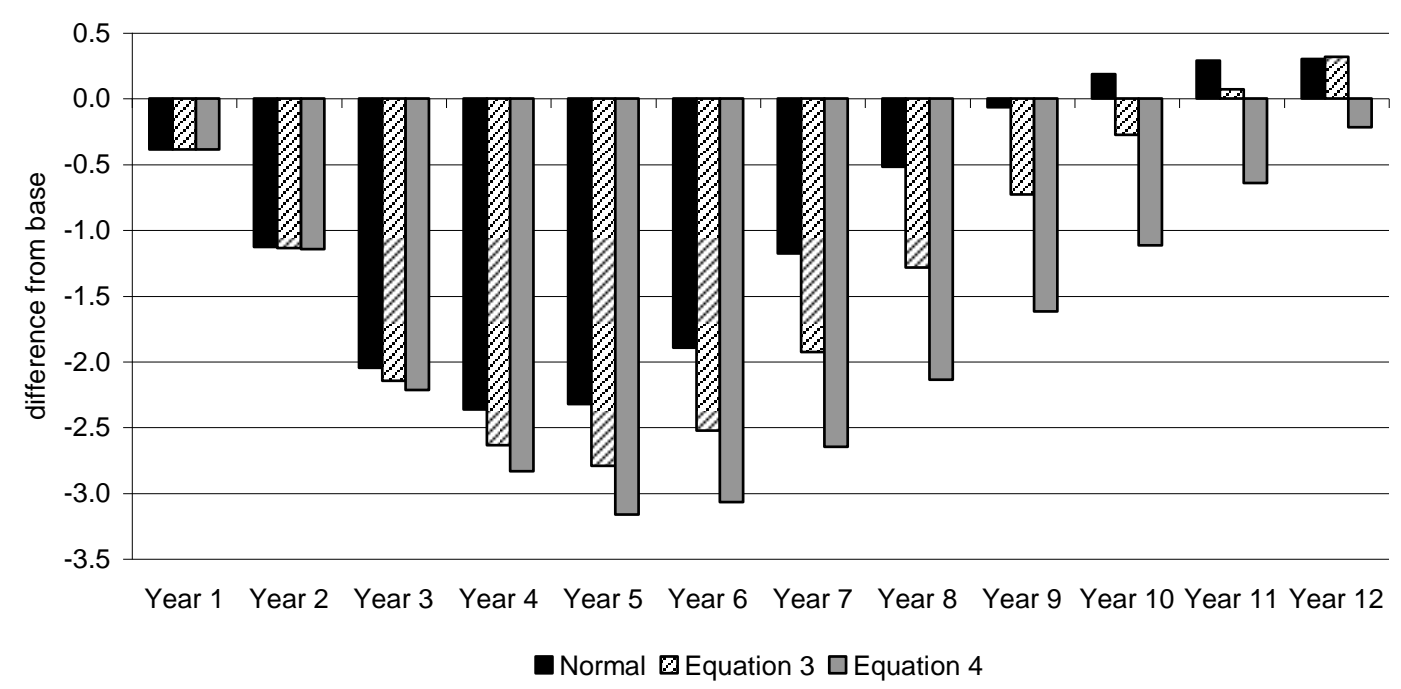

Notes: Impact of policies described in table 1 on GDP, if introduced in 'normal' times under the standard version of NiGEM and with the augmented wage equations (3) and (4) described above.

Source: NiGEM simulations

\section{Figure 8. Impact on unemployment rate}

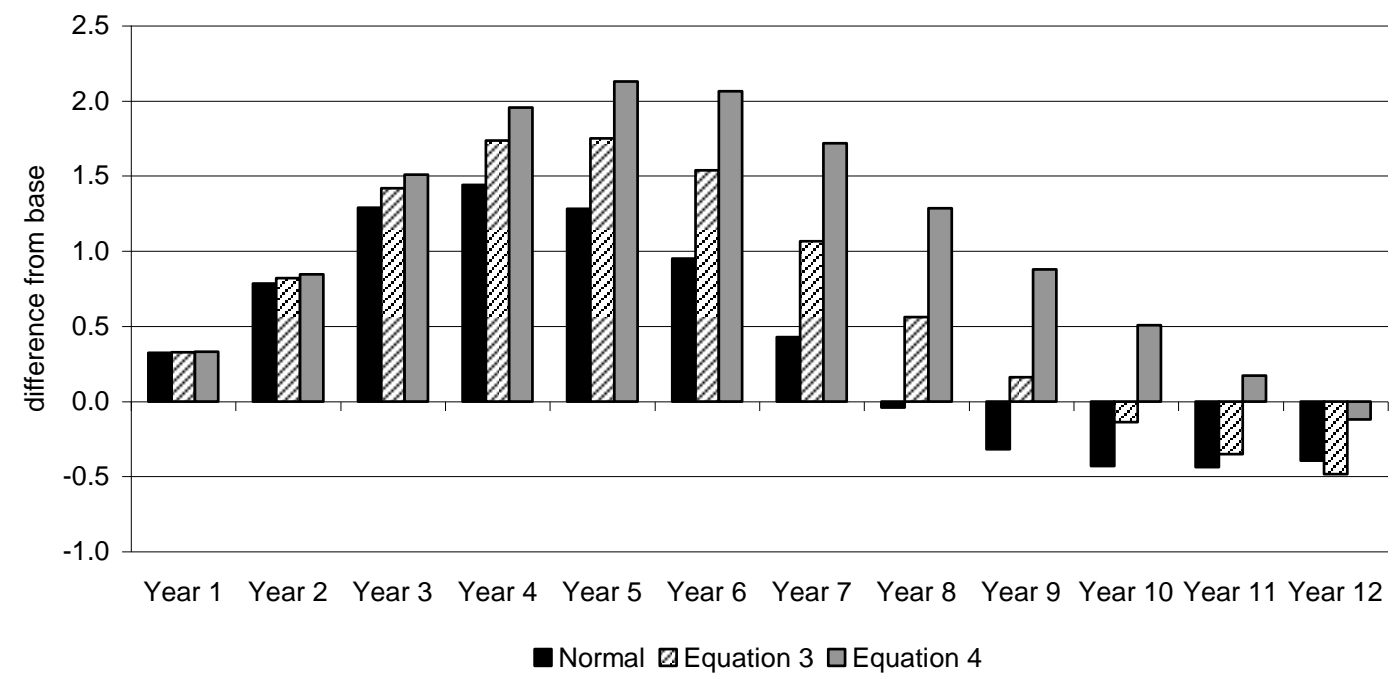

Notes: Impact of policies described in table 1 on unemployment rate, if introduced in 'normal' times under the standard version of NiGEM and with the augmented wage equations (3) and (4) described above.

Source: NiGEM simulations

\section{Cumulative impacts}

Based on the results of the scenarios presented above, we can calibrate an estimate of the cumulative impacts on the economy from introducing fiscal tightening starting in 2011, rather than postponing the measures until output and unemployment had recovered from the downturn. The impact is partly driven by the heightened magnitude of fiscal multipliers, and exacerbated by the prolongation of their impact due to hysteresis effects. As an illustrative scenario, we assume that the interest rate response is impaired, with no adjustment in the long-term interest rate. We allow for moderately high liquidity constraints, so assume that the number of liquidity constrained agents is roughly double what it is in normal times (model 4 
in the Appendix), and model wages as in equation 3 above, with the long-term unemployed exerting 60 per cent less pressure on wages than total unemployment. Changing this set of assumptions could lead to a stronger or weaker impact on the economy than shown here, as demonstrated by the sensitivity of the results to the scenarios reported above.

Figures 9-11 illustrate projections for GDP growth, the unemployment rate and government debt as a ratio to GDP that we would anticipate under three different scenarios. The first reflects our assessment of the fiscal consolidation programme for 2011-17 as reported in table 1, introduced during the current environment of a depressed economy with moderately high liquidity constraints. This is consistent with the baseline forecast for the UK presented in this Review, and we designate this scenario as 'consolidate during a depression'. The second scenario illustrates the path that we would have expected had the consolidation programme been delayed until economic recovery was well underway, which model-based estimates suggest would have been by about 2014 in the absence of early fiscal tightening. The programme detailed in table 1 is implemented, but the timing is shifted so that it is enacted over the period 2014-20, with no consolidation measures introduced 2011-14. We designate this scenario as 'consolidate during normal times'. Finally we illustrate a scenario that shows the economic path that would have been expected in the absence of any consolidation programme, which we designate as 'no consolidation'. Scenarios 2 and 3 are identical for the first three years.

\section{Figure 9. GDP growth under three consolidation scenarios}

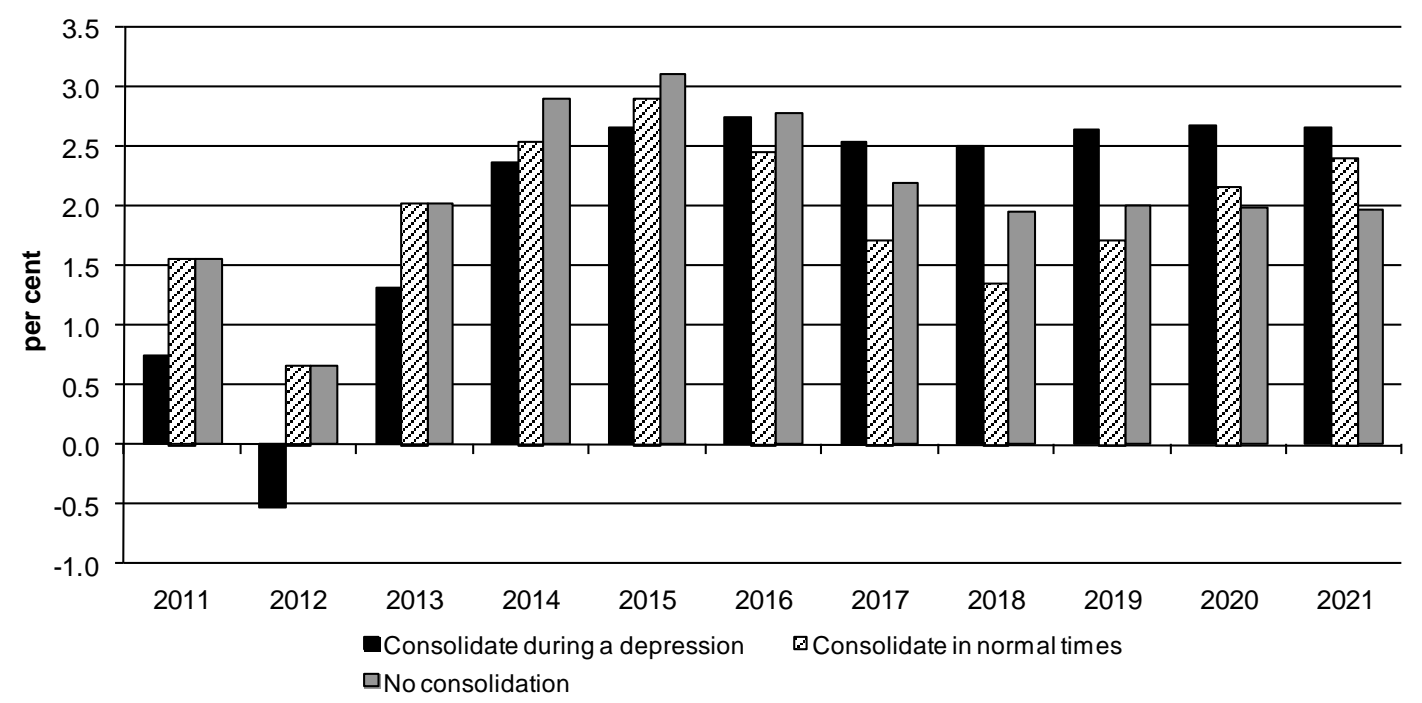

Notes: Consolidation starting in 2011 during a depression, consolidation starting in 2014 when the economy has returned to 'normal', no consolidation.

Source: NiGEM simulations 
Figure 10. Unemployment rate under three consolidation scenarios

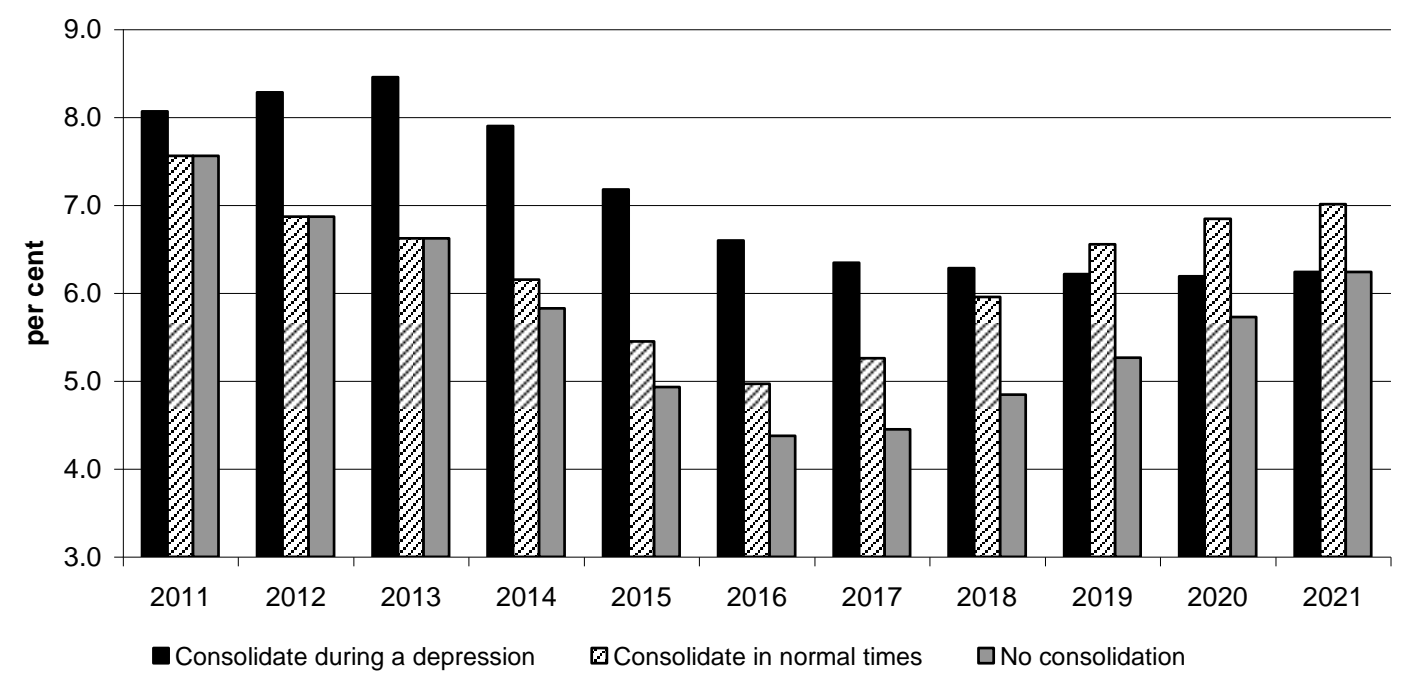

Notes: Consolidation starting in 2011 during a depression, consolidation starting in 2014 when the economy has returned to 'normal', no consolidation.

Source: NiGEM simulations

\section{Figure 11. Government debt under three consolidation scenarios}

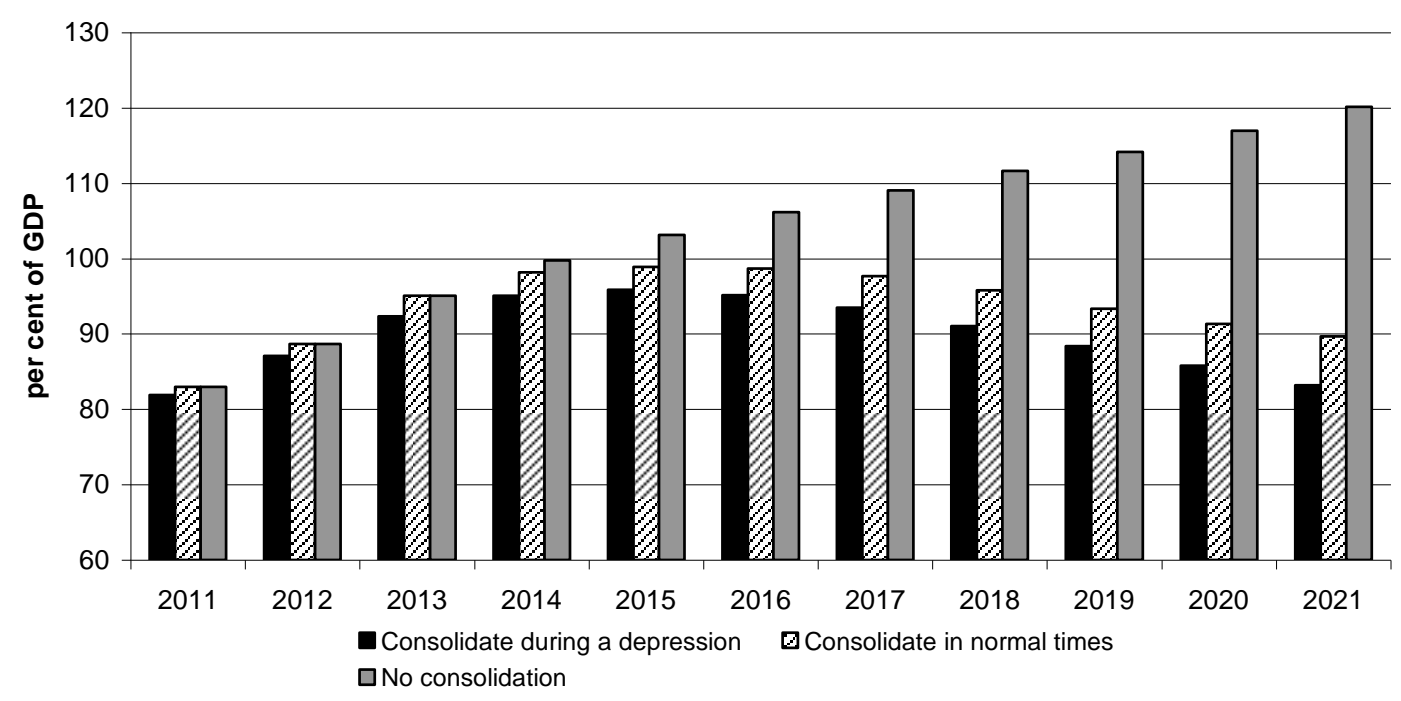

Notes: Consolidation starting in 2011 during a depression, consolidation starting in 2014 when the economy has returned to 'normal', no consolidation.

Source: NiGEM simulations

A number of studies have looked at the links between the risk premium on government borrowing and fiscal sustainability, captured by current or expected values of the general government deficit or the stock of government debt (Laubach, 2009; Baldacci and Kumar, 2010; Schuknect et al, 2010; Bernoth and Erdogan, 2012 and others). These studies suggest that rising government debt is likely eventually to put upward pressure on interest rates, so that fiscal tightening is likely to be necessary at some point. Figure 11 indeed illustrates that in the absence of any fiscal tightening, the stock of government debt would have been on a steadily rising and almost certainly unsustainable path over the next decade. The option not to consolidate at all, therefore, was and is not a viable one. However, the differences between the debt profiles reflecting early consolidation and delayed consolidation are relatively modest, and the likely impact on interest rates is therefore small. Empirical estimates, on 
average, point to a 2-4 basis point rise in interest rates for a 1 per cent of GDP rise in the government debt to GDP ratio. A 10 percentage point differential, therefore, would be expected to induce at most a 40 basis point rise in borrowing costs. Even this may overstate the impacts for non-Euro Area countries. IMF (2012b) points out that, "fiscal indicators such as deficit and debt levels appear to be weakly related to government bond yields for advanced economies with monetary independence".

The scenarios suggest that the recession in 2012 could have been avoided had fiscal tightening measures been delayed. Table 2 details the differences between the two scenarios in level terms. Our estimates indicate that the cumulative loss of output from early consolidation accumulated over the period 2011-21 amounts to £239 billion in constant 2010 prices. This is equivalent to $161 / 2$ per cent of 2010 GDP (or about 1.3 per cent of total output over the entire period). These losses are sustained despite the fact that the growth rate of GDP is expected to be higher after 2016 under the early consolidation scenario compared to the delayed consolidation scenario, as consolidation measures in the latter are ongoing until 2020. In the long run, the level of GDP in the three scenarios should converge to a common level. Figure 1 indicates that the negative impact on output of the fiscal consolidation programme initiated in normal times can be expected to dissipate by eleven years after the onset of the programme, so that by 2025 the growth rate of GDP should converge in all three scenarios. A substantial permanent deadweight loss associated with the early consolidation programme will persist, as the amplified losses in the early years will not be fully offset by amplified gains once recovery sets in.

Similarly, the unemployment rate is expected to be higher until 2018 under the early consolidation programme than it would have been with a delayed fiscal tightening, as shown in figure 10. In the long run, the level of the unemployment rate can be expected to converge to the same level in all three scenarios. It may take 10-11 years for these effects to feed through. The 'consolidate in a depression' scenario sees the unemployment rate falling below that of the 'consolidation in normal times' scenario over the period 201921 . This reflects the fact that the delayed consolidation programme comes to an end only in 2020, whereas in the early consolidation scenario the recovery has been ongoing for three years, and the differences can be expected to dissipate by 2024. More importantly, the unemployment rate in the delayed scenario would never be expected to exceed 7 per cent. 
Table 2. GDP in £billion, 2010 prices under two scenarios

\begin{tabular}{|c|c|c|c|c|}
\hline & $\begin{array}{c}\text { Consolidate } \\
\text { during a } \\
\text { depression }\end{array}$ & $\begin{array}{c}\text { Consolidate } \\
\text { in normal } \\
\text { times }\end{array}$ & Difference & $\% 2010$ GDP \\
\hline 2011 & 1478 & 1489 & 11 & 0.8 \\
\hline 2012 & 1476 & 1505 & 29 & 2.0 \\
\hline 2013 & 1495 & 1535 & 40 & 2.7 \\
\hline 2014 & 1531 & 1575 & 44 & 3.0 \\
\hline 2015 & 1572 & 1622 & 49 & 3.4 \\
\hline 2016 & 1614 & 1660 & 45 & 3.1 \\
\hline 2017 & 1654 & 1686 & 33 & 2.2 \\
\hline 2018 & 1694 & 1708 & 14 & 1.0 \\
\hline 2019 & 1738 & 1737 & -1 & -0.1 \\
\hline 2020 & 1785 & 1775 & -10 & -0.7 \\
\hline 2021 & 1832 & 1817 & -15 & -1.1 \\
\hline
\end{tabular}

Sum 2011-

$\begin{array}{lllll}2021 & 17869 & 18109 & 239 & 16.3\end{array}$

Source: NiGEM simulations

\section{Conclusions}

The concern today is that the Great Recession starting in 2008 and the consequent early fiscal tightening policies may lead to significant losses in output and a protracted period of high unemployment. The analysis presented in this note indicates that these concerns are wellfounded. Under current policy plans the unemployment rate is expected to remain above 7 per cent until 2016. Had tightening measures been delayed until economic recovery was well underway, cumulation output on the period 2011-21 would have been significantly higher, and the unemployment rate would have been expected to rise no higher than 7 per cent over the next decade. In light of the above results, it can be argued that fiscal policy choices have to be considered in the light of the monetary policy response function. When monetary policy is constrained by the zero lower bound on interest rates, the impact of fiscal policy (the fiscal multiplier) will be magnified compared to normal times. The health of the banking sector is also an important determining factor. When unemployment is high or job security low, a greater percentage of households and firms are likely to find themselves liquidity constrained. This is likely to be particularly acute when the downturn is driven by an impaired banking system, as lending conditions will tighten beyond what would be expected in an ordinary downturn. Heightened liquidity constraints amplify the effects of any contractionary policy on output and unemployment.

This study is necessarily narrow, and does not take into account a number of factors that may also cause the impacts of a policy innovation introduced in normal times to differ from that observed during a prolonged downturn. For example, there may be additional effects on savings behaviour, hysteresis effects may also be deeper and more prolonged, and interest rates may respond more significantly if the link between the magnitude of government debt and government borrowing premia is important.

Ball (1996) finds that inadequate responses to recessions have contributed to hysteresis in some countries. A corollary conclusion is that policies of deficit reduction in the presence of 
substantial output shortfalls will have adverse impacts in both the short and long run. The standard policy prescription - to delay deficit reduction until after recovery is clearly under way and the output shortfall significantly reduced - remains valid.

\section{Notes}

1 The fiscal multiplier is generally defined as the expected impact on output in the first year, following a policy innovation that raises spending or cuts taxes by 1 per cent of GDP ( $e x$ ante).

2 Fiscal multipliers tend to be less than 1, primarily due to import leakages, the anticipated monetary policy response, and an offset through the consumption channel through savings.

3 The policy rule followed is the standard two-pillar rule in NiGEM, which is described in Barrell et al. (2012).

4 IMF's recent report, 'United Kingdom 2012 Article IV Consultation', IMF Country Report No. 12/190, also focuses on the labour market channel of hysteresis to explain changes in the NAIRU. It stresses a slightly different channel, namely, labour employment protection laws as the driver of hysteresis impacts.

5 Comparing the short-term and long-term unemployed, evidence shows that the outflow rates for the long-term unemployed have always been lower than that for the short-term unemployed. The lower outflow rate for the long-term unemployed, compared to the short-term unemployed, is called negative duration dependence. The most natural interpretation is that the long-term unemployed have a lower chance of finding a job.

6 Authors' calculations based on data from The U.S. Bureau of Labor Statistics.

7 Holland (2012) assesses the impact of labour force withdrawal in the US on potential output. 


\section{References}

Auerbach, A.J. and Gorodnichenko, Y. (2012), 'Fiscal multipliers in recession and expansion", American Economic Journal: Economic Policy, 4(2), pp. 1-27.

Baldacci, E. and Kumar, M. (2010), 'Fiscal deficits, public debt and sovereign bond yields', IMF Working Paper 10/184.

Ball, L.M. (1996), 'Disinflation and the NAIRU', NBER Reducing Inflation: Motivation and Strategy, pp. 167-94.

Barrell, R., Fic, T. and Liadze, I. (2009), 'Fiscal policy effectiveness in the banking crisis', National Institute Economic Review, 207.

Barrell, R., Holland, D. and Hurst, A.I. (2012), 'Fiscal consolidation Part 2: fiscal multipliers and fiscal consolidations', OECD Economics Department Working Paper No. 933

Bernoth, K. and Erdogan, B. (2012), 'Sovereign bond yield spreads: a time-varying coefficient approach', Journal of International Money and Finance, 31, pp. 639-56.

Blanchard, O.J. and Diamond, P. (1994), 'Ranking, unemployment duration and wages', Review of Economic Studies, 61(3), pp. 417-34.

Calmfors, L. and Lang, H. (1995), 'Macroeconomic effects of active labour market programmes in a union wage-setting model', Economic Journal, 105(430), pp. 601-19.

DeLong, J.B. and Summers, L.H. (2012), 'Fiscal policy in a depressed economy', Brookings Papers on Economic Activity 2012.

Elsby, M.W.L. and Smith, J.C. (2010), 'The great recession in the UK labour market: a transatlantic perspective', National Institute Economic Review, 214, p. R26.

Holland, D. (2012), 'Reassessing productive capacity in the United States', National Institute Economic Review, 220.

Ilzetzki, E., Mendoza, E.G. and Végh, C.A. (2010), 'How big (small?) are fiscal multipliers?', Centre for Economic performance Discussion Paper 1016, October.

IMF (2012a), Fiscal Monitor Update, July.

— (2012b), United Kingdom 2012 Article IV Consultation, Country Report No. 12/190.

Laubach, T. (2009), 'New evidence on the interest rate effects of budget deficits and debt', Journal of the European Economic Association, 7, pp. 858-85.

Machin, S. and Manning, A. (1999), 'The causes and consequences of long term unemployment in Europe', Handbook of Labour Economics, Vol. 3.

Manning, A. (1993), 'Wage bargaining and the Phillips curve: the identification and specification of aggregate wage equations', Economic Journal, 103(416), pp. 98-118.

Nickell, S.J. (1987), 'Why is wage inflation in Britain so high?', Oxford Bulletin of Economics and Statistics, 49(1), pp. 103-28.

OECD (2009), 'Adjustment to the OECD's method of projecting the NAIRU', OECD Economics Department.

Schuknecht, L., von Hagen, J. and Wolswijk, G. (2010), 'Government bond risk premiums in the EU revisited. The impact of the financial crisis', European Central Bank Working Paper, No. 1152. 


\section{Appendix A. Fiscal multipliers and liquidity constraints}

In this appendix we illustrate the sensitivity of the estimated fiscal multipliers to assumptions on the short-term income elasticity of consumption and investment. In the presence of perfect capital markets and forward-looking consumers with perfect foresight, households will smooth their consumption path over time, and consumer spending will be largely invariant to the state of the economy or temporary fiscal innovations. However, some fraction of the population at any given time is liquidity constrained with little or no access to borrowing, so that their current consumption is largely restrained by their current income. The share of the population that is liquidity constrained will affect the short-term income elasticity of consumption, given by parameter $b_{1}$ from equation (A1) below:

$$
\begin{gathered}
\Delta \ln \left(C_{t}\right)=\lambda\left\{\ln \left(C_{t-1}\right)-\left[a+b_{0} \ln \left(T A W_{t-1}\right)+\left(1-b_{0}\right) \ln \left(R P D I_{t-1}\right)\right]\right\} \\
+b_{1} \Delta \ln \left(R P D I_{t}\right)+b_{2} \Delta \ln \left(N W_{t}\right)+b_{3} \Delta \ln \left(H W_{t}\right)
\end{gathered}
$$

where $C$ is consumption, $T A W$ is total asset wealth, which is the sum of net financial wealth $(N W)$ and tangible wealth $(H W), R P D I$ is real personal disposable income, $\square$ is the difference operator, and the remaining symbols are parameters.

Cross-country differences in the average short-term income elasticity of consumption have a strong correlation with the tax multipliers, as highlighted by Barrell, Holland and Hurst (2012). However, access to credit is dependent both on credit history and on current income, and so is necessarily sensitive to the state of the economy. As unemployment rises, a greater share of the population will be unable to access credit at reasonable rates of interest - at precisely the moment when they are in need of borrowing to smooth their consumption path. This means that consumption is likely to be cyclical, and that $b_{1}$ is likely to be time varying and dependent on the position in the cycle. Following a banking crisis the effects can be expected to be particularly acute, as banks tighten lending criteria, as discussed by Barrell, Fic and Liadze (2009). This also suggests that fiscal multipliers are dependent on the state of the economy - especially tax innovation multipliers - and this is consistent with recent studies such as Delong and Summers (2012) and Auerbach and Gorodnichenko (2012).

Investment is always more cyclically sensitive than consumer spending, but these effects may be particularly amplified when the banking system is impaired. We model investment as an adjustment towards a desired capital stock. The stock of capital is one of the factors of production underlying the supply-side of the economy, and a profit maximizing condition that sets the marginal product of capital equal to its price (the user cost of capital) leads to the following long-run relationship.

$$
\ln \left(\frac{K}{y c a p}\right)=\alpha_{1}-\sigma \ln (\text { user })
$$

Where $K$ is the capital stock, ycap is potential GDP, user is the tax adjusted user cost of capital and $\square$ is the elasticity of substitution between labour and capital.

Embedded within a dynamic framework, the standard equation to model capital demand in NiGEM is given by: 


$$
\Delta \ln \left(K_{t}\right)=\delta_{1}-\delta_{2}\left[\ln \left(K_{t-1}\right)-\ln \left(\text { ycap }_{t+12}\right)+\sigma \ln \left(\text { user }_{t-1}\right)\right]+\delta_{3} \Delta \ln \left(K_{t-1}\right)+\delta_{4} \Delta \ln \left(y_{t}\right)+\delta_{5} \Delta \ln \left(y_{t-1}\right)
$$

Where $y$ is real GDP.

From this we determine investment through the identity relationship:

$$
I_{t}=K_{t}-(1-d e p) K_{t-1}
$$

Where $I$ is gross investment and $d e p$ is the depreciation rate.

We distinguish between housing and business investment as the dynamics of behaviour are significantly different for the two. The parameters $\square_{4}$ and $\square_{5}$ may be sensitive to the position of the cycle and particularly to the health of the banking sector.

In order to assess the sensitivity of fiscal multipliers to the magnitude of liquidity constraints, we run our consolidation scenario under a series of eleven different models, allowing the parameters $b_{1}, \square_{4}$ and $\square_{5}$ to rise incrementally. The models allow $b_{1}$ to rise from 0 , which implies perfect capital markets with no liquidity constraints, to 1, which implies that all current income is spent on consumption, with no scope for saving and smoothing consumption. In our standard model, the estimated parameter for $b_{1}$ is given by 0.17056 , suggesting a relatively low level of liquidity constraints historically. Barrell, Holland and Hurst (2012) put this into an internationally comparative context, which suggests that UK liquidity constraints are on the low side, but not out of line with other advanced economies. Choosing appropriate values for $\square_{4}$ and $\square_{5}$ is somewhat less straightforward, as a 1 per cent increase in the capital stock is equivalent to a 50-100 per cent increase in the investment flow. The estimated parameters of the standard NiGEM model are $0.042\left(\square_{4 \mathrm{~b}}\right)$ and 0.013 $\left(\square_{5 \mathrm{~b}}\right)$ for business capital and $0.015\left(\square_{4 \mathrm{~h}}\right)$ and $0.01\left(\square_{5 \mathrm{~h}}\right)$ for housing capital. We calibrate the parameters by centering so that the NiGEM standard model is between model 2 and 3 in the table below. The $\square_{5}$ parameters are set to maintain the ratio of $\square_{4} / \square_{5}$ in the standard version of NiGEM.

The estimated impact on GDP of the consolidation scenario, under different assumptions on the short-run income elasticity of consumption and investment are reported in table A1 below. With no liquidity constraints, we would expect the policy to reduce output by just 0.2 per cent in the first year, while with no options for borrowing to smooth consumption we would expect output to decline by 1.4 per cent. Our standard model predicts that the fiscal policy would reduce output by 0.4 per cent in the first year, under normal conditions with limited liquidity constraints. Differences between the different models dissipate by year 7 . 
Table A1. Impact of consolidation programme on UK GDP, under different short-term income elasticities of consumption and investment

\begin{tabular}{|c|c|c|c|c|c|c|c|c|c|c|c|}
\hline Model & 1 & 2 & 3 & 4 & 5 & 6 & 7 & 8 & 9 & 10 & 11 \\
\hline Short-run income elasticity of consumption $\left(b_{1}\right)$ & 0.0 & 0.1 & 0.2 & 0.3 & 0.4 & 0.5 & 0.6 & 0.7 & 0.8 & 0.9 & 1.0 \\
\hline $\begin{array}{l}\text { Short-run capital-output elasticity (business) } \\
\left(\delta_{4 \mathrm{~b}}\right)\end{array}$ & 0.035 & 0.042 & 0.049 & 0.057 & 0.064 & 0.071 & 0.078 & 0.086 & 0.093 & 0.100 & 0.107 \\
\hline $\begin{array}{l}\text { Short-run capital-output elasticity (housing) } \\
\left(\delta_{4 h}\right)\end{array}$ & 0.012 & 0.015 & 0.018 & 0.020 & 0.023 & 0.026 & 0.029 & 0.031 & 0.034 & 0.037 & 0.040 \\
\hline Year 1 & -0.22 & -0.30 & -0.39 & -0.48 & -0.58 & -0.68 & -0.80 & -0.92 & -1.05 & -1.20 & -1.36 \\
\hline Year 2 & -0.44 & -0.51 & -0.59 & -0.67 & -0.76 & -0.84 & -0.93 & -1.01 & -1.10 & -1.18 & -1.27 \\
\hline Year 3 & -0.77 & -0.84 & -0.90 & -0.97 & -1.03 & -1.09 & -1.14 & -1.19 & -1.23 & -1.25 & -1.26 \\
\hline Year 4 & -1.20 & -1.29 & -1.39 & -1.48 & -1.58 & -1.67 & -1.77 & -1.87 & -1.97 & -2.08 & -2.19 \\
\hline Year 5 & -1.80 & -1.90 & -2.00 & -2.10 & -2.19 & -2.29 & -2.39 & -2.49 & -2.59 & -2.69 & -2.79 \\
\hline Year 6 & -2.13 & -2.21 & -2.29 & -2.36 & -2.43 & -2.49 & -2.56 & -2.62 & -2.67 & -2.72 & -2.76 \\
\hline Year 7 & -2.04 & -2.06 & -2.08 & -2.09 & -2.09 & -2.08 & -2.07 & -2.04 & -2.00 & -1.95 & -1.89 \\
\hline Year 8 & -1.66 & -1.66 & -1.65 & -1.64 & -1.61 & -1.58 & -1.54 & -1.49 & -1.43 & -1.36 & -1.28 \\
\hline Year 9 & -1.16 & -1.16 & -1.15 & -1.14 & -1.12 & -1.11 & -1.09 & -1.07 & -1.05 & -1.04 & -1.03 \\
\hline Year 10 & -0.63 & -0.63 & -0.64 & -0.64 & -0.64 & -0.64 & -0.66 & -0.67 & -0.70 & -0.74 & -0.80 \\
\hline Year 11 & -0.14 & -0.14 & -0.16 & -0.17 & -0.18 & -0.20 & -0.23 & -0.27 & -0.32 & -0.38 & -0.47 \\
\hline Year 12 & 0.26 & 0.26 & 0.23 & 0.22 & 0.20 & 0.17 & 0.13 & 0.09 & 0.04 & -0.02 & -0.08 \\
\hline
\end{tabular}

